Fikrah: Jurnal Ilmu Aqidah dan Studi Keagamaan

issn 2354-6147 eissn 2476-9649

journal.stainkudus.ac.id/index.php/fikrah

DOI: http://dx.doi.org/10.21043/fikrah.v7i1.5160

Volume 7 (1) 2019, 1-20

\title{
Multiculturalism in the Islamic Texts View and its Relevance to Interreligious Harmony in Indonesia
}

\author{
Abdurrohman Kasdi ${ }^{1 *}$, Umma Farida $^{2}$ \\ ${ }_{1,2}^{2}$ Institut Agama Islam Negeri Kudus, Kudus, Indonesia \\ 1*abdurrohmankasdi@iainkudus.ac.id, 2ummafarida@iainkudus.ac.id
}

\begin{abstract}
Abstrak
Studi ini menggambarkan konsep multikulturalisme dan relevansinya untuk mewujudkan harmonisasi agama di Indonesia. Quran dan hadis adalah sumber utama teks Islam. Data diperoleh melalui dokumentasi. Data yang diperoleh dianalisis secara deskriptif-deskriptif. Studi ini mengungkapkan pluralitas etnis dan agama adalah fakta empiris bahwa Indonesia telah ditakdirkan. Indonesia adalah bangsa yang terdiri dari berbagai suku, adat, budaya, dan agama. Studi ini menunjukkan bahwa multikulturalisme dalam pandangan teks-teks Islam memiliki relevansi makna dan fungsi yang sesuai untuk dikembangkan dan diinternalisasi dalam proses mentransformasikan nilai-nilai dari beragam komunitas dan masyarakat Indonesia.

Kata kunci: Multikulturalisme, Quran, hadits, harmonisasi umat beragama
\end{abstract}




\begin{abstract}
The study describes the concept of multiculturalism and its relevance to realizing the religious harmonization in Indonesia. Quran and hadith are the main source of Islamic text. The data gain through documentation. The obtained data analyzed criticallydescriptive. The study reveals the ethnic and religious plurality is the empirical fact that Indonesia has been destined. Indonesia is a nation consisting of various tribes, customs, cultures, and religions. The study shows that multiculturalism in the view of Islamic texts has the relevance of the meaning and function that is appropriate to be developed and internalized in the process of transforming the values of the diverse communities and peoples of Indonesia.
\end{abstract}

Keywords: Multiculturalism, Qur'an, hadith, harmonization of religious people

\title{
Introduction
}

The plurality of ethnic and religion is an empirical fact which is naturally unavoidable in Indonesia that has been destined to be a nation consisting of various tribes, customs, cultures, and religions. The Indonesian nation of more than 200 million people and inhabiting thousands of islands from Sabang to Merauke has become a large and pluralistic nation (Fakih, 2015; Harahap, 2016; Qomar, 2016). Pluralism and diversity of ethnicity, race, religion, and culture owned by the Indonesian people can become a capital as well as potential conflicts (Harahap, 2016; Masrshall, 2018; Yani, Haidar, Warsono, \& Sadewo, 2018). The cultural diversity that exists in the various regions in Indonesia indeed enriches cultural treasures and becomes a valuable capital to build a multicultural Indonesia. But a large number of cultures also have potential to divide and become a fertile ground for conflict and social jealousyif there isn't any communication between the cultures of the area (Mishra \& Kumar, 2014).

One of trigger of social conflicts that often arise in Indonesia is denial the reality of pluralism and multiculturalism (Gurses \& Rost, 2017; Masrshall, 2018). The plurality of Indonesian society according to J. S. Furnivall as quoted by Syamsul Arifin, shows the segregation between each social group (Arifin, 2009). The development of plurality, described by Furnivall is not beneficial for the future of society in Indonesia, because it has potential to lead to open social conflict. However, this plurality is no longer a threat of segregation if the management of multiculturalism goes well. 
Indonesia's pluralistic context has increasingly been tested lately with the emergence of intolerant attitudes that have triggered conflict and various acts of violence in many regions in Indonesia. Awareness of the importance of pluralism arises because of the failure of the state in establishing a spirit of nationalism which is considered to emphasize the unity rather than the diversity(Mishra \& Kumar, 2014). Pluralism in many ways - ethnicity, religion, race, culture, and class - that should be a treasure and a capital to build a nation are often manipulated by the authorities to achieve their political interests(Amirrachman, 2015; Yani et al., 2018). Even when social conflicts flare up in the regions, it is not uncommon for pluralistic reality to be covered in the name of 'unity' and 'national stability' as happened in the reign of the new order government (1966-1998).

The concept of SARA (Suku, Agama, Ras, Antargolongan / Tribe, Religion, Race, and Inter-Group) introduced by the New Order government is the construction to describe plurality in Indonesia. However, in the next understanding, there are differences in the meaning of the position of SARA in the social interaction of the community (Baidhawy, 2010; Wang \& Uecker, 2017; Wise \& Driskell, 2017). The government means SARA as a source of division. Therefore, it becomes a knowledge or a reality that is taboo. This meaning is ironic, considering that on the one hand, the official ideology of the state recognizes the plurality of SARA, even that plurality has supported the realization of a pluralistic Indonesian society under the jargon of Unity in Diversity (Bhinneka Tunggal Ika). But on the other hand, the practice was never implemented, but instead made it a symbol of labeling of discourses and actions that were contrary to the state, which led to the conclusion that SARA was a disruption to the stability and the development (Wasino, 2013).

The phenomenon of conflict and violence in Indonesia has become inevitable and has even penetrated on the religious life. Setara Institute, one of the NGO in Indonesia that conducts research and advocacy on democracy, political freedom and human rights noted that social conflicts in Indonesia that started from cases of intolerance that had occurred throughout 2017 were 155 cases. There were an additional 3 cases in February 2018. They are the dissolution of the social service of the Catholic Church of St. Paul in Pringgplayan, Bantul, Yogyakarta; expulsion of a monk in 
Tangerang, Banten; and attacks on the St Lidwina Catholic Church, Trihanggo, Sleman (Setara Institute, 2017).

The involvement of religious factors in the conflict invites a concern. It is because a religion, which has a mission to create peace, is involved in the conflict. Even though normatively-theologically, all religions in the world are met with the same universal mission so that although they still have a particularity, there are some aspect of universality in religions. Among their universal missions are that religions give affirmations to the spiritual needs of humans, as well as being a forum for the implementation of social and humanitarian deeds (Baidhawy, 2007; Wang \& Uecker, 2017). The closeness of human relations with God is not only in the practice of religious rituals but also through the creation of social harmony, the defense of justice, and alleviation of humanity from backwardness.

If the Indonesian people can manage the existing of pluralism positively, then social conflict or religious conflict should not need to occur. According to the study of Bromley (2002), the development of conflict usually goes through the three stages, namely: Latent tension, nascent conflict, and intensified conflict. The first stage, latent tension, manifests in the form of misunderstanding with one another, but they do not involve themselves in the conflict. This stage can also be called autistic conflict. In the second stage, nascent conflict, begins to appear in form of conflict even though it has not included ideological phrases and organized mapping of opposing parties. Whereas in the third stage, intensified conflict, conflict develops in an open form accompanied by the radicalization of movements between conflicting parties, and the entry of parties into the arena of conflict (Bromley, 2002).

The Indonesian state should massively and eagerly emphasize the importance of multicultural education for its people to minimize conflict, and even the multicultural education need to include in curriculum taught in schools and colleges. It is because multiculturalism respects the peculiarities of certain local community cultures and equates them with other community cultures(Bosca, 2016; Hanurawan \& Watenvorth, 1997; Supriyatno, 2017). Multiculturalism also has a constructive view that local cultural 
communities are beneficial for the development of a culture of democracy and mutual respect. Thus, multiculturalism has an open view of diversity (Suyahman, 2016).

Islam as a religion that spreads love to the universe (rahmatan lil 'alamin) has provided the foundation for the importance of pluralism recognition or multiculturalism that exists in humans (Beck, 2016; Zuhdi, 2018). Islam not only regulates its vertical relationship with God but also pays attention to its horizontal relationship with fellow humans. A peaceful life between humans is an ideality that Islam wants to realize. Muslims can live safely side by side with non-Muslims. Through its source of teachings, namely the Qur'an and Hadith, Islam calls on its people to develop mutual respect in diversity.

The harmony in diversity reflected in the multiculturalism finds its urgency with the teachings of the Qur'an and Hadith, but unfortunately, there are not many Muslims who understand that velues, therefore sometimes it gives the impression that Islam tends to teaching be exclusive and intolerant towards others. The alienation of Muslims towards Islamic teachings is to respond to the needs for study and research on the Islamic texts in responding to social and religious problems that occur in society, including those related to multiculturalism. This study aims to describe the management of multiculturalism and interreligious harmony in Indonesia based on the Qur'an and Hadith.

\section{Methods}

The study focused on multiculturalism according to the Qur'an and Hadith and its relevance in realizing the harmonization of religious people in Indonesia. Considering the data examined in this study rests on library data, so this study uses the library research method with the semantic approach. The supporting data of this study were obtained through documentation techniques by examining documents and literature, both primary and secondary, related to multiculturalism according to the Islamic texts, especially those derived from the Qur'an and Hadith, and its relevance in realizing the harmonization of religious people in Indonesia. The collected data is then analyzed descriptively-critically. 


\section{Multiculturalism in the Islamic Texts}

Multiculturalism in the Islamic texts, namely the Qur'an and Hadith, can be classified as follows: First, freedom of religion and recognition of the existence of religion, ethnicity, race, and other groups. The Qur'an mentions this cosmos as alalamin, which means that this nature has a variety of types, including humans who live in this cosmos with the various origins, races, ethnicities, religions or beliefs, and characters (Surah Al-Anbiya: 107). The verse shows that the presence of the Prophet Muhammad PBUH was to spread love to the universe. Because all humans inhabit the same world, humans do not deserve to kill, expel, and each other only because of different ethnicities, religions, races, descendants, and others. Recognition of the existence of something different in religion, race, ethnicity, and others also necessitates the importance of being fair and proportional in addressing that diversity. Fair means positioning something portion and attitude that is supposed to be, impartial and does not interfere with the existence of other parties (Berkes, 2010). Surah Ash-Shura: 15 and Surah Al-Ma'idah: 8 confirmes that recognizing the existence of other religions and cultures, and respecting their adherents is also part of a fair attitude.

Second, learning to live together in diversity. Humans are social creatures that are not likely to confine themselves to not interact with other people. Therefore, it is inevitable for humans to learn to live together with other human beings who may have differences with us, both seen from their tribes, religion or beliefs, races, and ethnicities (Surah Al-Baqarah: 213). The Qur'an shows that humans originated from one people. This verse is related to Surah Yunus: 19 which states that humans were once only one group (ummatan wahidatan), then they argued. One group here is meant to be the same people in the belief in monotheism. But after that, it was no longer so, because they were at loggerheads.

The diversity that is a necessity of man should not be a source of disputes over differences, but instead, need to develop the mutual respect for these differences (Berkes, 2010). The importance of living together in diversity is also confirmed in Surah al-Hujurat: 13 that all humans have the same position before God even though they differ in ethnicity, position, and race. There is no difference between one tribe and 
another. There is no difference in human values between men and women because there is no difference in human values between men and women because everyone is born of a man and a woman.

Third, building good integrity and avoiding bad thinking (Surah Al-Hujurat: 6). Developing an attitude of mutual understanding and mutual trust between one people and others despite the different religions, ethnicities, races, and others accompanied by clarification and confirmation in receiving any information. As social beings who are required to live together and side by side, everyone should base themselves on something that is truly known and clear. The process of selecting information based on logical considerations and values that have been taught by God. Thus, Islam emphasizes that living in a multicultural society requires to be selective in receiving any information. But this attitude must be accompanied by mutual understanding and mutual trust, not spying and bad thinking first. Because if developing these last two attitudes, it will raise doubts in the community and cripple them as explained in Surah Al-Hujurat: 12. The Prophet PBUH also said, "Stay away from you in a bad attitude, because bad thought is the most utter lie, do not look for each other's faults, do not spy on each other, do not hate each other, do not turn back to each other, and be a servant of God's brothers." (Al-Bukhari, 1980; Muslim, 2001).

The command to have the integrity has a strong correlation with honesty, or in Arabic known as ash-shidqu, has a real meaning or is true. It means a match between speech and action or between information and reality. This honesty can be classified into five types. First, honesty in intention or will, namely someone is motivated to do something or act sincerely, without any tendency. Second, honesty in speech, namely someone who says according to what he knows or accepts. Third, honesty in deeds, namely someone who acts according to his conscience and mind. Fourth, honesty in a promise, namely someone who keeps his promise. He just said a commitment or a pledge he knew he could fulfill. Fifth, honesty related to reality, which means someone applies honesty to everything he experiences in his life.

Honesty is necessary for living in a society both monoculture and multicultural society. Honesty will lead to peace and goodness, live in harmony side by side despite 
the different ethnicities, religions, races, languages, and cultures. Muhammad PBUH said, "Honesty leads to righteousness, and the righteousness guides to heaven, a man has been honest until Allah recorded him as a sincere person. Meanwhile, the lie leads to tyranny, and the tyranny shows to hell, and indeed a man has lied until Allah recorded him as a liar." (Al-Bukhari, 1980; Muslim, 2001).

Fourth, upholding mutual respect and understanding (Surah Al-Hujurat: 11). The Qur'an teaches that humans can respect one another. Do not mock each other and belittle them, because these two attitudes will easily ignite hostility and lead to prolonged conflict. Every human being has the privileges that can be different from others. In the above verse, God reminded that people who make fun are not better than the person he mocked. Thus the person who mocked made multiple mistakes, namely: Disparaging and mocking, and being belittled better than him. In this case, it also includes people who mention the shortcomings of others with the aim of laughing at the person concerned, either with words, actions, or behavior.

In a society often people or groups who are strong will underestimate the weak, people with high social status disparage the low. The intelligent people mock the stupid. The healthy people sometimes mock the weak or disabled. The handsome and beautiful people sneer the ugly. The rich people ridicule the poor. Surah Al-Hujurat has anticipated avoiding mocking and disparaging which can cause tension and division in society. In the Hadith of Sa'ad ibn Sahal stated that someone passed in front of the Prophet, then the Prophet asked the person sitting next to him, "What do you think about this person?" He replied, "O Messenger of Allah, he is a noble person, he is worthy of his proposal." The Prophet was silent, then another man passed in front of the Prophet, he asked again, "What about this?" He replied, "O Messenger of Allah, this person is among the poor Muslims if he is proposing a marriage he certainly will not be accepted." Then the Prophet said, "The latter is better than the contents of your body than the first." (Al-Bukhari, 1980).

Surah Al-Muthaffifin: 29-39 reiterated the prohibition on making fun of others. The Messenger of Allah PBUH also always remind that God does not see someone from the form or property, but God sees the heart and deed (Muslim, 2001). In line with this 
hadith, Abu Hurairah narrated that the Prophet Muhammad PBUH said, "On the Day of Judgment Allah will call," I have the origin, and you also have the parentage. The most piety among you are the noblest according to Allah, but you deny it by saying Fulan son of Fulan is better from Fulan son of Fulan, on this day I will exalt my origin and take off your lineage, then which ones are the piety?" (Muslim, 2001). Regarding people of different faiths, the Qur'an forbids denouncing their worships. It is relevant to the conditions of Indonesian people who live side by side with other religions, who are encouraged to respect each other and prohibit them from making fun of each other as stated in Surah Al-An'am: 108.

Fifth, realize the conflict resolution and non-violence reconciliation (Surah AshShura: 40). The Qur'an teaches that each person will receive a reward for his good deeds. At the same time, the Qur'an also affirms that the retribution of a crime is a similar crime. Related to multiculturalism, that if a group faces unfair treatment, then he has the right to defend himself. This verse shows that each believer will not be willing to be abused and persecuted only because of differences in ethnicity, race, and so on. If harassment and persecution continue to occur, then it is permissible to defend themselves against it, but the way to mediation and prioritizing patience is better for them as stated in Surah As-Shura: 39, "and deliberate in completing their case" also in Surah Al-Hajj: 39, "It has been permitted to fight for those who were persecuted, and verily Allah is truly Almighty to help them."

\section{Discourse on Harmonization of Religious People in Historical Trajectories}

The principle of religious freedom is explained clearly in the Qur'an, such as the Qur'an's recognition of religious pluralism (Surah Al-Kafirun: 1-6), a firm statement that no force in embracing religion (Surah Al-Baqarah: 256), the prohibition of forcing adherents of other religions to embrace Islam (Surah Yunus: 99); appeal to religious believers to find the similarities between each religions (Surah Al-Imran: 64); encourage of goodness, fairness, and harmony between them (Surah al-Mumtahanah: 8-9). Unfortunately, Islamic teachings that prioritize the values of humanism, pluralism, and inclusiveness are not widely disseminated in society so it is not surprising that the faces 
of Islamic societies in various regions appear fierce and unfriendly, different from the portraits displayed by early generations of Muslims who were known to be full of tolerance, friendship and brotherhood (Setiawati, 2012).

The idea of harmonization between the religious people put forward by the Qur'an has been implemented by the Prophet in the community of Medina. At that time, They had a diverse religion and wanted to build a life together which manifested in a joint commitment in the form of the Medina Charter. This charter serves as the text of the exemplary and fundamental constitution for Muslims and at the same time becomes the character of their culture. The Medina Charter can also accommodate various interpretations regarding the composition of the multicultural people, the rights and obligations of the authorities and the government, and the fundamental role of the state.

Historical data shows that Medina's charter was not only a theoretical framework but also carried out by all layers of plural Medina society. The most important factor in the realization of this charter is the example of the Prophet, himself, who became the leader of the Muslim and Non-Muslim communities in Medina. This example makes a real contribution to the growth of diversity that enables all religions to coexist peacefully. Although the existence of the Medina Charter is separate from the Qur'an and Hadith, it is still compatible with both because the substance of the Medina charter is in line with the teachings of the Qur'an and Hadith (Baidhawy, 2015). By taking the spirit of the Qur'an, Hadith, Medina Charter and other religious texts, the harmonization of religious people has always attracted the attention to study since the past until now because of multiculturalism and harmonization between the religious people is a process that must always be sought, not a finished good.

However, Islam is not the only religion that teaches the importance of mutual respect and understanding in navigating the lives of a multicultural society. For example, Christianity with the Bible also teaches the importance of loving God and human (Matthew 22: 37, Corinthians: 13) and doing good to fellow humans despite different religions, "You have heard the word: Love your neighbor and hate your enemy. But I say to you, Love your enemies and pray for those who persecute you. For thus you 
become children of the Father in Heaven, who issues the sun to the wicked and the good and sends rain to the righteous and the unrighteous" (Matthew 5: 43-45). This text shows that the Bible also hints at the importance of willingness to do good and think clearly about others by taking a very extreme example of the enemy. The attitude towards the enemy was also ordered to do good and pray for him.

In line with the emergence of discourses or the concept of multiculturalism, there was also a personal effort about institutional ideas in religious circles to look for the roots of inter-religious harmony (Grishaeva, 2012). The Islamic and Christian world has noted the continuity of activities among the religious people to find it and call for objectivity in viewing religions. For example, Ali ibn Hazm in his book al-Milal wa anNihal (Ibn Hazm, 1980) and Joachim Wach in his book The Comparative Study of Religion (Wach, 1969) argued that there is no single religion is true in the sense that other religions are wrong. However, all religions must contain the truths.

The hope of realizing the harmonization of religious people has become the hope of every believer in the world, without exception in Indonesia. The state plays a role in fostering inter-religious harmony in Indonesia. The government is present in the process of religious formation in each religious community as well as inter-and interreligious communication so that the potential of the nation can unite well and become the nation's capital development force towards an advanced, independent, just and prosperous society. The government also guarantees the freedom of worship according to their respective beliefs as shown in Article 29 of the 1945 Constitution and the First Precept of Pancasila. Subsequently, in 1947, the Government established the Ministry of Religion with one of the tasks in managing community development, both Islamic, Christian, Catholic, Hindu, and Buddhist.

At least there are three goals of the development of harmony: First, the internal harmony of religious people. Second, inter-religious harmony. Third, harmony between religious people and the government. The internal harmony of religious people is an effort to bring out mutual respect between followers of the same religion but differ in ritual religious practices. The inter-religious harmony is an attitude of mutual respect between followers of different religions. The last is the harmony between the religious 
people and the government. It shows that the relationship between religious people and the government is not a dominative relationship, but rather a relationship that is the partnership and consultative (Izzah, 2013). One of the three targets of religious harmony is pursued through the establishment of FKUB (Forum Komunikasi Umat Beragama, the Religious Harmony Forum) in each province, regency or city based on the Joint Regulation of the Minister of Religion and Minister of Internal Affairs no. 8 \& 9 of 2006 .

\section{Diversity in Indonesian Society}

Indonesia is called by Geertz (1963) as a new state of old societies because Indonesia is a country formed from old communities in the form of kingdoms, cultural communities, ethnic groups, religions, and so forth. The existence of a variety of communities that inhabit Indonesia makes its society a pluralistic society characterized by diverse cultures, ethnicities, and historical backgrounds. Maksum and Ruhendi (2004) describe the plurality of the Indonesian people and classify it into two parts: Horizontal and vertical plurality. The differences in religion, ethnicity, clothing, geography, food, and culture show the plurality of the Indonesian people horizontally. While their plurality vertically can be seen from the differences in educational, economic, residential, occupational, and socio-cultural levels (Wasino, 2013).

Multiculturalism in Indonesia requires the existence of joint self-structuring efforts to build a life together in a stable and dynamic society. According to Molan (2016), living together in diversity requires stability and dynamism because the life that only prioritizes the stability can indeed make a calm society without turmoil, but it cannot grow the seeds of creativity, change, development, and initiation (Molan, 2016). The stability should be based on the freedom and the internal-esoteric moral consciousness and tested with qualified critical arguments so that it is not easily swayed by external-exoteric situations. On the contrary, building a dynamic multicultural society cannot only be based on mere dynamics, because it will create a turbulent and easily provoked society which ultimately results in the destructive conflicts and disrupt the order of life together. The group or individual movements that are too dynamic in expressing themselves in the wild ways and free without limits can threaten the stability 
of the community itself. A lot of energy must be devoted to overcoming this too dynamic society. Therefore, stability must be built with dynamics. Stability and dynamics are two aspects needed in a shared life.

The harmonization of humanity -despite different religions- in life is a necessity. Here is the urgency of understanding about multiculturalism in realizing the interreligious harmony community. According to Harahap (2011), there are at least three approaches to the study of multiculturalism and its relevance to the harmonization of religious people. First, a normative approach, a study that looks at the relationship of religions from the normative text. Second, the historical approach, which sees the harmonics from the standpoint of historicity, social facts, and friendly behavior among the religious adherents throughout history. Third, the rational-liberal approach that sees the relationship of religions with the rational and dynamic approach, and views most sacred texts as the interpretable things. It even goes deeper into the message of universal values contained behind the religious texts.

\section{Managing the Multiculturalism and Harmonization of Inter-Religious People in Indonesia}

It is not easy to manage the multiculturalism condition in Indonesia. If the existed diversity doesn't addressed properly will lead to conflict and disputes that are vulnerable to violence. Therefore, the multiculturalism movement cannot be a single movement, but it involves all aspects of humanity that guarantees justice, equality, honesty, and other positive attitudes (Gurses \& Rost, 2017; Yani et al., 2018). Even according to Molan (2016), creating a harmonious, stable, and dynamic multicultural society in Indonesia needs to be supported by the following attitudes:

First, Freedom and humanitarian equality. Freedom and equality are two important aspects in the life of a multicultural society. First, the realization of freedom and human equality. Freedom, on the one hand, will give every human the opportunities to develop and express themselves, pursue their dreams, and show their identities. As for equality, it will form the unity and harmony in a shared life that makes the life together to be calm, harmonious, mutual respect and mutual recognition. 
If freedom creates differences and diversity, then the equality emphasizes the living together in a calm and harmonious society that will create unity. The freedom and equality manifest both in the public and private area. It is because the public always demands that the entire community be treated equally and not discriminatory. The state as the public world should treat its people in the same levels without any discrimination, while freedom is more towards the private area. The state must regulate the public areas which are joint property to provide the conditions that allow for the development of private freedom. On the contrary, the state must also regulate that private freedom does not undermine the public domain which is a common area to develop themselves in togetherness.

Second, mutual respect. Freedom and equality must be balanced with mutual respect and tolerance. Everyone should be able to feel his freedom in the real sense, namely, the freedom that does not violate the limits of other people's freedom, because everyone has the human rights that must be respected. The multicultural communities should have an understanding of mutual respect for rights and obligations. It is because in the rights of every human being is found a guarantee of freedom, while in their obligations there is a guarantee of equality. A person may be free to claim his rights, but he also has the obligations to respect the other's rights. The mutual respect implies that the attitudes and actions taken by a person are indeed worthy of respect. The award does not need to be forced, but it must be an awareness that comes from within the heart itself. Therefore, the multiculturalism needs to be supported by the steps to continue to realize that basically everyone can respect each other.

Third, Justice and Civilization. The multicultural communities are vulnerable to conflict, division, and disharmony. The trigger factor is not because of diversity, but because of injustice. The justice must be balanced with the civilization, because justice is a demand for a natural balance, while the civilization is natural polishing to become human-faced. It does not mean that there is a conflict between nature and the human, but it means that the two get the weight of balanced attention. Someone who only demands the justice without building a civilized attitude tends to be uneasy and continues to rage in the revenge. Conversely, too civilized people will tend to be victims of manipulation. An attitude that is too easy to forgive and forgive without ever 
demanding justice will be easily underestimated. Or in other words, justice without the civilization is easy to be merely revenge, while the civilization without justice tends to invite the manipulative attitudes (Budirahayu, Wijayanti, \& Baskoro, 2018). In a multicultural society, diversity is a necessity. But the inter-community, inter-cultural, and inter-cultural relations still open up the possibility of top-down, dominantsubordinate, and superior-inferior relations. The discrimination and injustice in the community interaction are easily found or even deliberately conditioned so that the management of multicultural communities still leaves the opportunities for the oppression of minorities who should continue to be avoided.

Fourth, honesty and humility. The multiculturalism can be implemented well in a conducive atmosphere full of honesty and humility. It is because the dishonesty creates the friction and disputes between the ethnic groups, cultures, beliefs, and gender. The honest and humble attitudes are related to the intention to build a harmonious life together. The honesty will give birth to mutual trust and mutual respect. The honest conflicts and cross-opinions will take place in healthy dynamics and bring forth the multiculturalistic agreements as well while the dishonesty will lead to the mistrust and mutual suspicion, which results to the unresolved destructive conflicts due to loss of the mutual trust (Molan, 2016). The honesty and humility can also minimize the violence. The conflict is different from the violence and a part of freedom that creates the dynamics for growth and development. The violence occurs when constructive conflicts increase to be destructive.

The management of multiculturalism in Indonesia requires multicultural education. Hilda Hernandez as quoted by Mahfud wrote that multicultural education is the recognition of the political, social, economic reality experienced by each individual in complex and diverse human meetings culturally, and reflect the importance of culture, race, sexuality, gender, ethnicity, religion, social status, and economy in the educational process (Mahfud, 2016). Education as a media for the transformation of science should be able to provide the values of multiculturalism by means of mutual respect for the diverse realities, both the background and base of the socio-cultural environment that surrounds them (Barakoska, 2013). 
The focus of multicultural education according to Tilaar is no longer directed to the mainstream culture by emphasizing the increasing of understanding and tolerance of individuals from minority groups towards the dominant mainstream culture, as has been emphasized in the intercultural education. But on the attitude of caring and willing to recognize their respective cultures, both cultural, religious, ethnic, majority and minority races. Therefore, this multicultural education curriculum should cover themes such as tolerance, the danger of discrimination, ethno-cultural and religious differences, mediation and reconciliation of conflicts, human rights, plurality, democracy, universal humanity, and others (Tilaar, 2002).

Multicultural education fosters the awareness that the lack of undertanding and recognition of 'other' cultures can lead to various poverty, injustice, oppression of others. It is because The multiculturalism, in essence, familiarizes every individual to be able to appreciate the diversity, including respecting followers of a religion that is different from him, by emphasizing that respecting diversity is part of religious teachings. The target of multiculturalism education is the students in schools and boarding schools, students who will become the activists in religious formation for the community, extension workers and religious leaders (UIN Jakarta, 2017). The interfaith dialogue also needs to be encouraged to find the similarities between the different religions and minimize the violence and conflict of religious groups.

\section{Conclusion}

The views and concepts of multiculturalism according to the Islamic texts, such as the Qur'an and Hadith, have the relevance of the meaning and function that is appropriate to be developed and internalized in the process of transforming the values of these diverse Indonesian peoples. Muslims as a majority can be a pioneer in managing multiculturalism in Indonesia through recognizing and respecting the diversity of community groups such as ethnicity, group differences, culture, gender, race, religion, social strata, differences of interests, beliefs, and traditions. It will help to realize the interreligious harmony and conducive social behavior in amidst the life of society and a pluralistic nation. The multiculturalism requires the joint self-regulation to build a life together in a stable and dynamic society. The multiculturalism that is not 
managed properly will lead to the conflicts and disputes that result in violence. Therefore, the multiculturalism movement in Indonesia is not a single movement, but it involves all aspects of humanity which include justice, equality, honesty, and other positive attitudes. The Indonesian Muslims as the majority people should be able to become the pioneers in the front line in managing the Indonesian multiculturalism and realizing the harmonization of religious people because the Qur'an and Hadith as their ways of life teach the positive attitudes in the management of multiculturalism. 


\section{Bibliography}

Al-Bukhari, M. I. B. (2004). Shahih al-Bukhari. Cairo: Dar al-Hadits.

Amirrachman, R. A. (2015). Book Review: Creating Multicultural Citizens. A Portrayal of contemporary Indonesian Education, written by Raihani. Bijdragen Tot de Taal-, Land-En Volkenkunde / Journal of the Humanities and Social Sciences of Southeast Asia, 171(2-3), 392-395. http://doi.org/10.1163/22134379-17102017

Arifin, S. (2009). Studi Agama: Perspektif Sosiologis dan Isu-isu Kontemporer. Malang: Universitas Muhammadiyah Malang Press.

Baidhawy, Z. (2007). Building harmony and peace through multiculturalist theology-based religious education: an alternative for contemporary Indonesia. British Journal of Religious Education, 29(1), 15-30. http://doi.org/10.1080/01416200601037478

Baidhawy, Z. (2010). The Problem Of Multiculturalism: Radicalism Mainstreaming through Religious Preaching in Surakarta. Journal Of Indonesian Islam, 4(2).

Baidhawy, Z. (2015). Piagam Madinah dan Pancasila: Prinsip-Prinsip Kehidupan Bersama dalam Berbangsa dan Bernegara. In W. G. A. Wahid, M. A. Darraz, \& A. F. Fanani (Eds.), Fikih Kebinekaan. Bandung: Mizan.

Barakoska, A. (2013). Multiculturalism as Important Characteristic of Contemporary Education. International Journal of Cognitive Research in Science, Engineering and Education, 1(1).

Beck, H. L. (2016). Islam in Indonesia. The Contest for Society, Ideas and Values, written by Carool Kersten. Bijdragen Tot de Taal-, Land-En Volkenkunde / Journal of the Humanities and Social Sciences of Southeast Asia, 172(4), 571-572. http://doi.org/10.1163/22134379-17204016

Berkes, L. (2010). The Development and Meaning of the Concept of Multiculturalism. International Relations Quarterly, 1(4), 27-32.

Bosca, L. C. (2016). Islam As An Object Of Study Of Anthropology - Incongruencies and Difficulties. Cogito, 8(4).

Bromley, D. G. (2002). Cults, Religion, and Violence. Cambridge: Cambridge University Press.

Budirahayu, T., Wijayanti, M. M., \& Baskoro, K. (2018). Understanding the multiculturalism values through social media among Indonesian youths pemuda Indonesia. Masyarakat, Kebudayaan Dan Politik, 31(4), 427-439. 
Fakih, F. (2015). Reading Ideology in Indonesia Today. Bijdragen Tot de Taal-, Land- En Volkenkunde / Journal of the Humanities and Social Sciences of Southeast Asia, 171(2-3), 347-363. http://doi.org/10.1163/22134379-17102007

Grishaeva, E. B. (2012). Multiculturalism as a Central Concept of Multiethnic and Polycultural Society Studies. Journal of Siberian Federal University, Humanities \& Social Sciences, 7(5), 916-922.

Gurses, M., \& Rost, N. (2017). Religion as a Peacemaker? Peace Duration after Ethnic Civil Wars. Politics and Religion, 10(2), 339-362. http://doi.org/10.1017/S1755048316000742

Hanurawan, F., \& Watenvorth, P. (1997). Multicultural Perspectives in Indonesian Social Studies Education Curriculum. The Journal of Education, 4, 265-275.

Harahap, S. (2011). Teologi Kerukunan. Jakarta: Prenada Media.

Harahap, S. (2016). The Image of Indonesia in the World: An Interreligious Perspective. IUP Journal of International Relations, 10(2).

Ibn Hazm, A. (1980). Al-Milal wa an-Nihal. Beirut: Dar al-Fikr.

Izzah, L. (2013). Melihat Potret Harmonisasi Umat Beragama di Indonesia. Religi, IX(1), $1-22$.

Mahfud, C. (2016). Pendidikan Multikultural. Yogyakarta: Pustaka Pelajar.

Maksum, A., \& Ruhendi, L. Y. (2004). Paradigma Pendidikan Universal. Yogyakarta: IRCISOD.

Masrshall, P. (2018). Conflicts in Indonesian Islam. Current Trends in Islamist Ideology, 23(1).

Mishra, S., \& Kumar, C. B. (2014). Understanding Diversity: A Multicultural Perspective. IOSR Journal Of Humanities And Social Science (IOSR-JHSS), 19(9), 62 66.

Molan, B. (2016). Multikulturalisme Cerdas Membangun Hidup Bersama yang Stabil dan Dinamis. Jakarta: Indeks.

Muslim. (2001). Shahih Muslim. Beirut: Dar al-Fikr.

Qomar, M. (2016). Islam Nusantara: Sebuah Alternatif Model Pemikiran, Pemahaman, dan Pengamalan Islam. El-HARAKAH (TERAKREDITASI), 17(2), 198. http://doi.org/10.18860/el.v17i2.3345 
Setara Institute. (2017). Terjadi 155 kasus intoleransi sepanjang 2017. Retrieved from https://www.merdeka.com/peristiwa/setara-institute-terjadi-155-kasus-intoleransisepanjang-2017.html

Setiawati, N. (2012). Tantangan Dakwah dalam Perspektif Kerukunan Antar Umat Beragama. Jurnal Dakwah Tabligh, 13(2), 259-267.

Supriyatno, T. (2017). Keberagaman Elemen Budaya Dalam Pembelajaran Pendidikan Agama Islam di Sekolah Dasar Islam di Malang. ULUL ALBAB Jurnal Studi Islam, 17(2), 218. http://doi.org/10.18860/ua.v17i2.3830

Suyahman, S. (2016). Implementation of Multicultural Education In Indonesia Between Expectations and Reality. In The 2nd International Conference on Science, Technology, and Humanity (pp. 202-215).

Tilaar, H. A. R. (2002). Perubahan Sosial dan Pendidikan: Pengantar Pedagogik Transformatif untuk Indonesia. Jakarta: Grasindo.

UIN Jakarta. (2017). No Title. Retrieved from https://www.uinjkt.ac.id/

Wach, J. (1969). The Comparative Study of Religion. Columbia: The Columbia University Press.

Wang, X., \& Uecker, J. E. (2017). Education, Religious Commitment, and Religious Tolerance in Contemporary China. Review of Religious Research, 59(2), 157-182. http://doi.org/10.1007/s13644-017-0286-5

Wasino, W. (2013). Indonesia: from Pluralism to Multiculturalism. Paramita, 23(2), $148-155$.

Wise, J., \& Driskell, R. (2017). Tolerance Within Community: Does Social Capital Affect Tolerance? Social Indicators Research, 134(2), 607-629. http://doi.org/10.1007/s11205-016-1449-4

Yani, M. T., Haidar, M. A., Warsono, W., \& Sadewo, F. S. (2018). The Religious Construction of Kiai on Pluralism and Multiculturalism. EL HARAKAH (TERAKREDITASI), 20(2), 175. http://doi.org/10.18860/el.v20i2.5074

Zuhdi, M. (2018). Challenging Moderate Muslims: Indonesia's Muslim Schools in the Midst of Religious Conservatism. Religions, 9(10), 310. http://doi.org/10.3390/rel9100310 